\title{
The European Journal of Epidemiology and the European Epidemiology Federation
}

\author{
Albert Hofman
}

(C) Springer Science+Business Media Dordrecht 2015

As you will read in the accompanying message from the current and former chair of the European Epidemiology Federation of the International Epidemiological Association, the European Journal of Epidemiology will from now on be affiliated with the EEF, through an agreement made with Springer, the publisher of EJE.
As editor-in-chief of EJE, I wholeheartedly support this affiliation and I agree with Professors Adele Seniori Costantini and Elisabete Weiderpass that this can bring mutual benefits. I look forward to a close collaboration between the board of the EEF and the editors and editorial board of EJE.

A. Hofman ( $\square)$

Rotterdam, The Netherlands

e-mail: a.hofman@erasmusmc.nl 